\title{
The Allolobophora sturanyi species group revisited: Integrated taxonomy and new taxa (Clitellata: Megadrili)
}

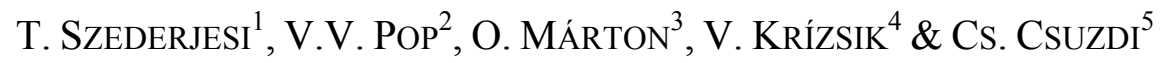 \\ ${ }^{1}$ Tímea Szederjesi, Department of Zoology, Plant Protection Institute, Centre for Agricultural Research, \\ Hungarian Academy of Sciences, Budapest, Hungary. \\ E-mail: t.szederjesi@gmail.com \\ ${ }^{2}$ Victor V. Pop, Institute of Biological Research, Cluj-Napoca, Romania. \\ ${ }^{3}$ Orsolya Márton, Conservation Genetics Group, Senckenberg Research Institute, Frankfurt, Germany. \\ ${ }^{4}$ Virág Krízsik, Molecular Taxonomic Laboratory, Hungarian Natural History Museum, Budapest. \\ ${ }^{5}$ Csaba Csuzdi, Department of Zoology, Eszterházy Károly College, Eger, Hungary.
}

\begin{abstract}
The Allolobophora sturanyi Rosa, 1895 species group is revisited using DNA barcoding and morphology. Barcoding results corroborated the previous treatment of the Allolobophora sturanyi subspecies and furthermore proved that the morphologically similar Allolobophora gestroides Zicsi, 1970 species belong to this species group. Elaboration of new samples from the Apuseni Mts resulted in discovery of a new subspecies A. sturanyi biharica ssp. nov. from the summit of the Bihor range, and a new species A. zicsica from the Vladeasa range similar to A. gestroides described from Northern Hungary.
\end{abstract}

Keywords. Earthworms, barcoding, COI, Carpathian Basin, new species

\section{INTRODUCTION}

$\mathrm{T}$ he Allolobophora sturanyi species group was first recognized by Csuzdi \& Pop (2008) through morphometric and biogeographic analysis of the species distributed in the Balkan and the Carpathian Basin and previously thought to be related to the Franco-Iberian Allolobophora dugesi (Rosa, 1886). The non-metric multidimensional scaling (MDS) and cluster analysis (CA) resulted in four well separated groups which showed distinct biogeographical patterns as well (Csuzdi \& Pop 2008). On the basis of the somewhat variable positions of the clitellum and tubercles, and furthermore the varying number of spermathecae, three lineages were treated as Allolobophora sturanyi subspecies, namely $A$. s. sturanyi Rosa, 1895, A. s. dacica (Pop, 1938) and A. s. dacidoides Bouché, 1973. The fourth clade differing markedly in the position of the clitellum from $A$. sturanyi, was described as a new species Allolobophora prosellodacica Csuzdi \& Pop, 2008.
In the recent years new samples were collected in the Apuseni Mts and the Carpathians including a specimen, in habitus resembling the $A$. sturanyi subspecies, but its clitellum begins much backwards, on segment 32 and therefore taxonomically similar to Allolobophora gestroides Zicsi, 1970 which was described from Northern Hungary.

Another sample, collected on and around the highest peak of the Bihor Mts (Cucurbăta Mare) contained also a strange species seemingly similar to A. sturanyi but it was not identical to any of the previously described subspecies.

To clear the positions of the newly discovered specimens and the species/subspecies in the $A$. sturanyi species group, in addition to the morphological investigation, we have carried out a molecular phylogenetic analysis using barcode sequences (COI) from all A. sturanyi subspecies and also A. gestroides. Unfortunately we were not able to collect fresh material from A. prosellodacica suitable for DNA extraction. 


\section{MATERIALS AND METHODS}

Earthworms were collected by the diluted formaldehyde method (Raw 1959) supplemented with digging and hand-sorting and also looking under stones and fallen logs. The worms were killed in 96\% ethanol and preserved in $75 \%$ ethanol. For molecular studies, some specimens were placed into $96 \%$ ethanol. The identified material is deposited in the Soil Zoology Collection of the Hungarian Natural History Museum (HNHM).

DNA extraction, amplification and sequencing were carried out in the Molecular Taxonomic Laboratory of HNHM according to the protocol described by Szederjesi \& Csuzdi (2015). In addition to the newly got barcodes several sequences were downloaded from the GenBank (Online Appendix 1).

DNA sequences were aligned with ClustalW implemented in MEGA 6.06 (Tamura et al. 2013) using the default settings.

Maximum Likelihood (ML) analysis was carried out using the online tool on Phylogeny.fr (Dereeper et al. 2008) with GTR G+I substitution model selected by the model selection process implemented in MEGA 6.06 (Tamura et al. 2013) and 100 bootstrap replication.

Bayesian inference was performed using the BEAST 1.8.2 software (Drummond et al. 2012) with the best fitting GTR G+I substitution model. The analysis was run for 10 millions of generations, sampling trees at every $1000^{\text {th }}$ generation. The first 2000 trees were discarded as "burn in" in TreeAnnotator v.1.8.2. The resulted tree was visualized with FigTree 1.4.2 (Rambaut 2014).

\section{RESULTS}

The A. sturanyi species group proved to be monophyletic in both (Bayesian and ML) analyses (Fig. 1) however, with moderate support $(79 \%$ and $61 \%$ respectively). The new species A. zicsica sp. nov. forms a quite well supported clade $(88 \%$ and $87 \%$ ) with A. gestroides and this clade is basal to the A. sturanyi subspecies. The relationships between the A. sturanyi subspecies are not quite clear and the Bayesian and ML analyses resulted in two different topologies. In the ML tree $A$. $s$. sturanyi is basal to the other subspecies and $A$. s. biharica is close to A. s. dacica however, in the Bayesian tree (Fig. 1B) A. s. biharica forms a moderately supported clade with A. $s$. dacidoides. The morphological characters support this latter hypothesis, because with $2 / 3$ pairs of spermathecae A. s. biharica from the summit of the Bihor Mts resembles A. $s$. dacidoides distributed in higher elevations of the Carpathians and characterized by $3 / 4$ pairs of spermathecae (Table 2 ).

According to the thorough analysis by Chang \& James (2011) the K2P distances lower than 9\% and higher than $15 \%$ can unambiguously be assigned to the same species or two different species, respectively. Between these two values there is an ambiguous range requires further considerations. The K2P genetic distances in the A. sturanyi species group (Table 1) vary between $10.6 \%$ and $14.1 \%$ which corroborate the previous taxonomic conclusion of Csuzdi \& Pop (2008) that dacica, dacidoides and also biharica ssp. nov. represent different subspecies of $A$. sturanyi.

The genetic distance (K2P) between A. gestroides and A. zicsica is $16.1 \%$ which proves their different specific statuses on molecular level too. It is worth noting that the genetic distance between $A$. gestroides and $A$. $s$. dacidoides is $14.6 \%$ however, the large morphological differences (Table 2) verify that they represent different species.

Table 1. K2P genetic distances between the A. sturanyi species group taxa. Intraspecific distances are in bold.

\begin{tabular}{|l|r|r|r|r|r|}
\hline & 1 & 2 & 3 & 4 & 5 \\
\hline A. s. dacica & $\mathbf{0 . 0 6 4}$ & & & & \\
\hline A. s. dacidoides & 0.141 & $\mathbf{0 . 0 7 6}$ & & & \\
\hline A. s. biharica & 0.124 & 0.106 & - & & \\
\hline A. s. sturanyi & 0.137 & 0.139 & 0.115 & - & \\
\hline A. gestroides & 0.169 & 0.146 & 0.157 & 0.171 & - \\
\hline A. zicsica & 0.179 & 0.176 & 0.169 & 0.182 & 0.161 \\
\hline
\end{tabular}




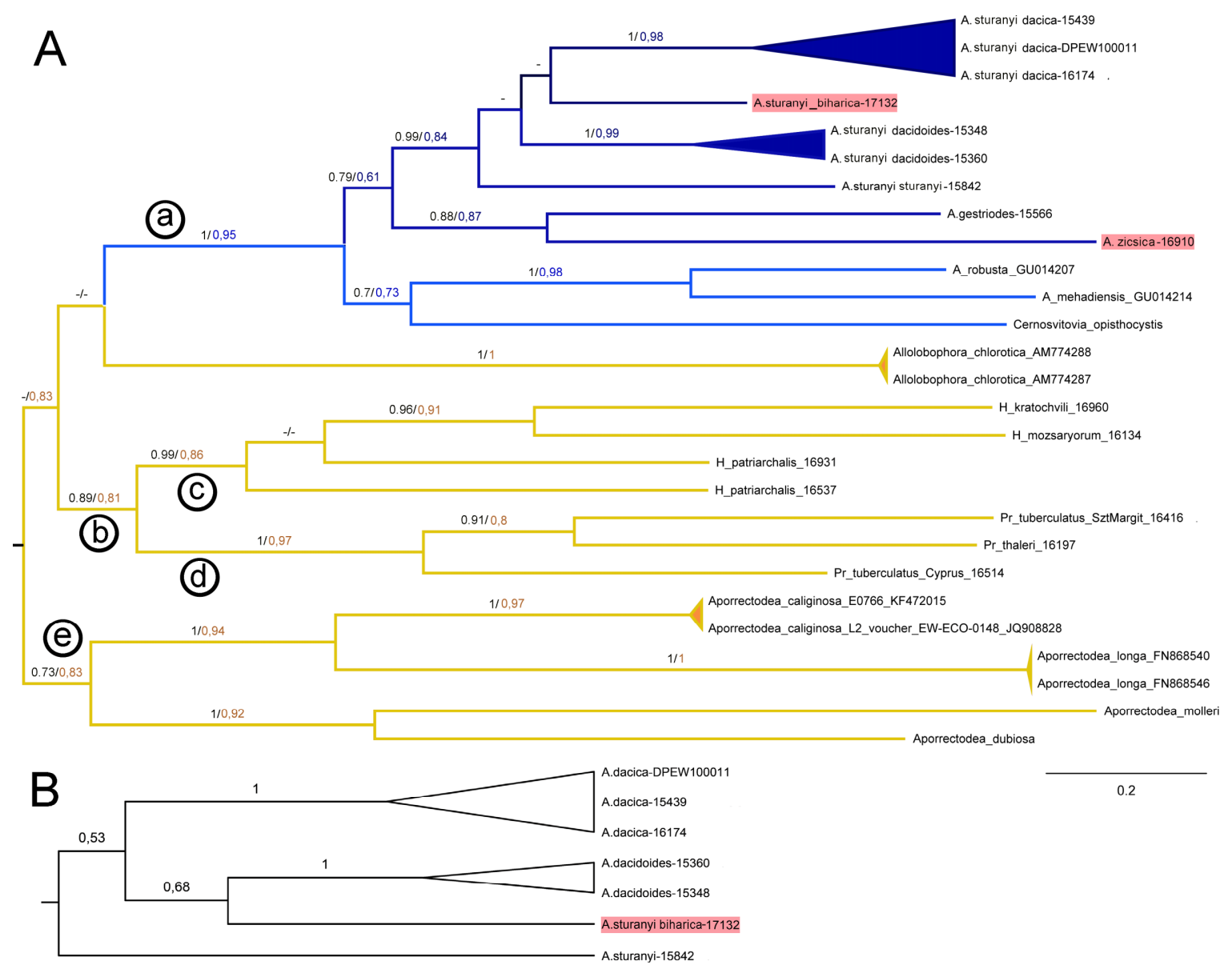

Figure 1. Phylogenetic reconstruction of the A. sturanyi species group (dark blue). Yellow clades represent outgroup species. Numbers above clades are Bayesian posterior probabilities/ bootstrap supports. A = ML tree, B = Bayesian tree.

\section{TAXONOMY}

\section{Allolobophora zicsica Szederjesi, Pop \& Csuzdi sp. nov.}

(Figures 2-3)

Material examined. Holotype. HNHM/16910, Romania, Săcuieu, Vf. Bogdanului, $46.81^{\circ} \mathrm{N}$ $22.92^{\circ} \mathrm{E}$, mixed pine-beech-oak forest, leg. J. Novák, T. Szederjesi, 19.04.2014.

Diagnosis. Length $45 \mathrm{~mm}$, diameter $3.5 \mathrm{~mm}$, setae closely paired. Pigmentation lacking. First dorsal pore on $8 / 9$. Clitellum on 32-40, tubercles on $1 / 235-1 / 240$. Male pore on 15 , large (Fig. 2). Nephridial pores invisible. Two pairs of vesicles in 11,12 ; spermathecae three pairs in $9 / 10-11 / 12$ in $c d$. Calciferous glands with well-developed diverticula in 10. Hearts in segments 6-11, nephridial bladders proclinate, J-shaped.

External characters. Holotype $45 \mathrm{~mm}$ long and $3.5 \mathrm{~mm}$ wide. Number of segments 125 . Colour pale, pigmentation lacking. Prostomium epilobous $1 / 2$ closed. First dorsal pore at intersegmental furrow 8/9. Setae closely paired. Setal arrangement behind clitellum: $a a: a b: b c: c d: d d=16.3: 1.3$ : 6.3:1:23.6 (Fig. 3). Male pores on segment 15, surrounded by glandular crescents. Nephridial pores invisible. Clitellum on segments 32-40. Tubercula pubertatis on segments $1 / 235-1 / 240$. Genital papillae on segments 13, 14, 16, 29, 30, 36-40ab. 


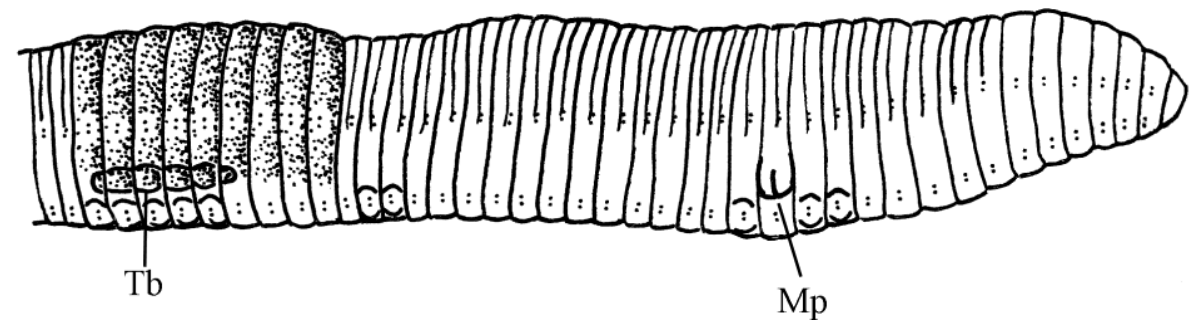

Figure 2. A. zicsica sp. nov. Ventrolateral view of the clitellar region. $\mathrm{Mp}=$ male pore, $\mathrm{Tb}=$ tubercle.

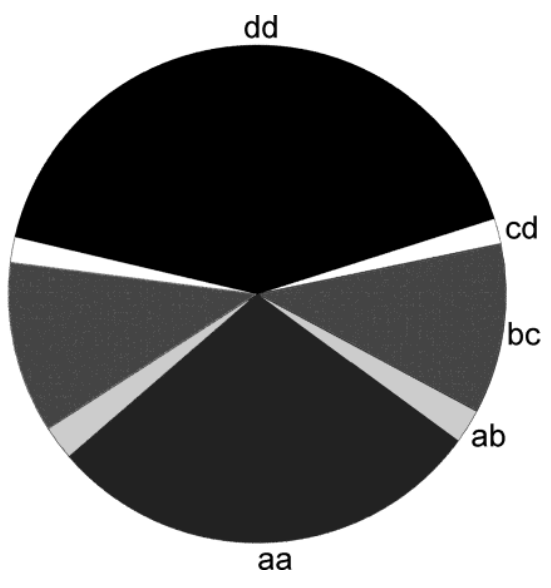

Figure 3. A. zicsica sp. nov. Setal arrangement.

Internal characters. Dissepiments 5/6-8/9 strongly thickened, 9/10 slightly thickened. Testes and funnels in segments 10-11, covered by perioesophageal testis sacs. Seminal vesicles in 11, 12. Spermathecae three pairs in $9 / 10,10 / 11,11 / 12$ with external openings near the setal line $c d$. Calciferous glands with well-developed diverticula in segment 10. Paired hearts appear in segments 611 , with a pair of small extraoesophageal vessels in 12. Nephridial bladders J-shaped with short proclinate ental part. Crop in segments 15-16, and gizzard in segments 17-18. Typhlosolis trifid, longitudinal musculature is of fasciculated type.

Etymology. The new species is named in honour of the late Prof. Dr. András Zicsi, the renowned earthworm taxonomist.

Remarks. A. zicsica sp. nov. is close to A. gestroides but differs in the position of the clitellum (32-40 vs. 29, 30-40,41), smaller biometry ( 45 x $3.5 \mathrm{~mm} v s .55-98 \times 4.3-5.2 \mathrm{~mm}$ ) and $16.1 \% \mathrm{~K} 2 \mathrm{P}$ genetic distance.

\section{Allolobophora sturanyi biharica Szederjesi, Pop \& Csuzdi ssp. nov.}

Figures (4-5)

Material examined. Holotype. HNHM/17133, Romania, Bihor Mts., before the peak of Curcubăta Mare, $1810-1685 \mathrm{~m}, 46^{\circ} 26.126^{\prime} \mathrm{N} 22^{\circ}$ 42.761'E, leg. Csuzdi Cs., 19.06.2015. Paratypes. HNHM/17151, 8 ex., locality and date same as of Holotype.

Diagnosis. Length 79-91 mm, diameter 3-3.5 $\mathrm{mm}$, setae closely paired. Pigmentation lacking. First dorsal pore on 9/10. Clitellum on 27-38, tubercles on $28-1 / 237$. Male pore on 15 , small (Fig. 4). Nephridial pores irregularly alternate between setal line $b-d$. Two pairs of vesicles in 11,12 ; spermathecae two or three pairs in $9 / 10$ $10 / 11(11 / 12)$ in $c d$. Calciferous glands with welldeveloped diverticula in 10. Hearts in segments 6-11, nephridial bladders proclinate, J-shaped.

External characters. Holotype. $84 \mathrm{~mm}$ long and $3 \mathrm{~mm}$ wide. Number of segments 205. Paratypes. $79-91 \mathrm{~mm}$ long and $3-3.5 \mathrm{~mm}$ wide, number of segments 179-182. Colour pale, pigmentation lacking. Prostomium epilobous 1/3 closed. First dorsal pore at intersegmental furrow $9 / 10$. Setae closely paired. Setal arrangement behind clitellum: $a a: a b: b c: c d: d d=24: 1.5: 13: 1: 48$ (Fig. 5). Male pores on segment 15, small. Nephridial pores irregularly alternate between setal line $b-d$. Clitellum on segments 27-38. Tubercula pubertatis on segments $28-1 / 237$. Genital papillae on segments 11, 13-16, 23, 24, 27, 28, $36 a b$.

Internal characters. Dissepiments 5/6-8/9 strongly thickened, 9/10 slightly thickened. Testes 


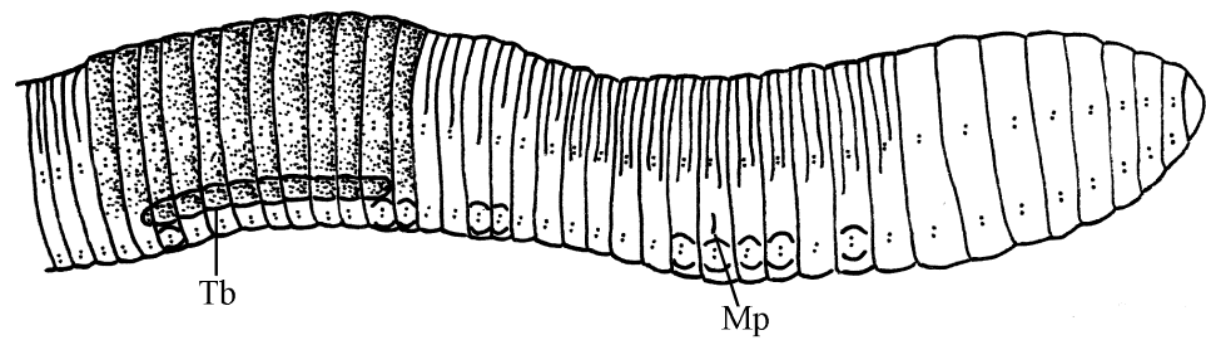

Figure 4. A. sturanyi biharica ssp. nov. Ventrolateral view of the clitellar region. $\mathrm{Mp}=$ male pore, $\mathrm{Tb}=$ tubercle

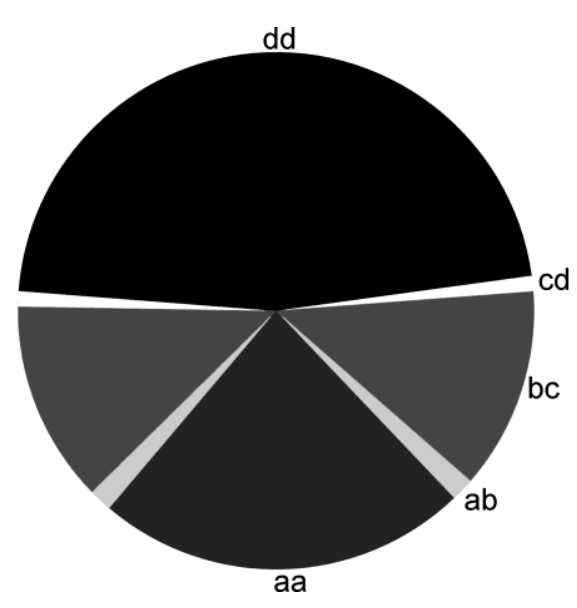

Figure 5. A. sturanyi biharica ssp. nov. Setal arrangement.

and funnels paired in segments $10-11$, covered by perioesophageal testis sac. Seminal vesicles in 11, 12. Spermathecae two or three pairs in $9 / 10$ 10/11(11/12) with external openings near the setal line $c d$. Calciferous glands with well-developed diverticula in segment 10. Paired hearts appear in segments 6-11, with a pair of small extraoesophageal vessels in 12 . Nephridial bladders J-shaped with proclinate ental part. Crop in segments 15-16, and gizzard in segments 17-18.
Typhlosolis bifid, longitudinal musculature is of fasciculated type.

Etymology. The species name refers to the type locality.

Remarks. A. s. biharica ssp. nov. is similar to A. s. sturanyi and A. s. dacidoides in having $2 / 3$ pairs of spermathecae but differs from both in the position of the clitellum and tubercles (Table 3) and also $11.5 \%$ and $10.6 \% \mathrm{~K} 2 \mathrm{P}$ genetic distances respectively.

\section{DISCUSSION}

Integrated taxonomy proved to be highly efficient in recognizing and expanding the previously defined Allolobophora sturanyi species group (Csuzdi \& Pop 2008). Both molecular taxonomic methods applied (Bayesian and ML analysis) highly supported the clade of the $A$. sturanyi subspecies (99\% and $84 \%$ respectively) and also there is a moderate support for inclusion of the A. gestroides and A. zicsica species pair into the sturanyi species group. This inclusion is supported by morphology as well (Table 2).

Table 2. Distinguishing characters of the species in the A. sturanyi species group.

\begin{tabular}{|c|c|c|c|c|}
\hline Species/subspecies & Clitellum & Tubercles & Receptacles & Segments \\
\hline A. sturanyi sturanyi & $27, \mathbf{2 8}-1 / n 39, \mathbf{3 9}$ & 29-38, 1/n39 & $3,9 / 10-11 / 12$ & $170-210$ \\
\hline A. sturanyi dacica & $\mathbf{2 8 , 2 9 - 3 7 , 3 8 , 3 9}$ & 30-37, $1 / n 38$ & $5,(4) 9 / 10-12 / 13,13 / 14$ & $165-182$ \\
\hline A. sturanyi dacidoides & $1 / n 27, \mathbf{2 7}-\mathbf{3 6}, 37$ & $1 / n 28, \mathbf{2 8}-\mathbf{3 6}, 37$ & $\mathbf{3 , 4}, 9 / 10-11 / 12,12 / 13$ & $119-152$ \\
\hline A. sturanyi biharica ssp. nov. & $1 / n 27, \mathbf{2 7}-\mathbf{3 8}$ & $\mathbf{2 8}-1 / 237,37$ & $\mathbf{2 , 3}, 9 / 10-10 / 11,11 / 12$ & 205 \\
\hline A. prosellodacica & $1 / n 24,25-1 / 236,36$ & 30-1/235, 35 & $39 / 10-11 / 12$ & $160-170$ \\
\hline A. gestroides & $29, \mathbf{3 0}-\mathbf{4 0}, 41$ & 35-40, 41 & $3,9 / 10-11 / 12$ & $163-201$ \\
\hline A. zicsica sp. nov. & $32-40$ & $1 / 235-1 / 240$ & $3,9 / 10-11 / 12$ & 125 \\
\hline
\end{tabular}


It is interesting to note that the other Dacian species analysed (Cernosvitovia opisthocystis, A. robusta and $A$. mehadiensis) formed a well-supported (100\% and 0.95$)$ clade with the sturanyi species group (clade $a$ in Fig. 1). This BalkanicCentral European clade of the Allolobophora species has already been recognized by Pop et al. (2005) and more recently in Domínguez et al. (2015). This clade ( $a$ here, and $c$ in Domínguez et al. 2015) contains species relegated previously into different genera by Mršić (1991) i.e. Cernosvitovia (opisthocystis, rebeli, dudichi), Karpatodinariona (dacica, dacidoides, sturanyi), Serbiona (mehadiensis, robusta) and Alpodinaridella (gestroides, gestroi). According to the accumulating morphological and molecular results it seems that these species form a well separated BalkanicCentral European genus, different from Allolobophora proper. As the type species of the senior synonym of Cernosvitovia is also involved $(C$. rebeli (Rosa, 1897)) the valid name of this genus should be Cernosvitovia.

It is also remarkable that the Helodrilus and Proctodrilus species also formed a monophyletic clade $(b)$ with quite high Bayesian and bootstrap support (89\% and $81 \%$ respectively) and Helodrilus (clade $c$ ) and Proctodrilus (clade $d$ ) proved to be exclusively monophyletic.

The closer relationship of Aporrectodea dubiosa (Örley, 1881) and Aporrectodea molleri (Rosa, 1889) was yet observed (Pop et al. 2005) and here they grouped together with the other Aporrectodea species (clade $e$ ) unlike to the trees in Domínguez at al. (2015) where they formed a clade with Allolobophora chlorotica (Savigny, 1826) (type species of the genus). Ap. dubiosa and Ap. molleri seems to be close also morphologically, both species are relatively large-bodied (120-150 mm), greenish, possess fasciculated musculature and backward shifted clitellum terminating after segment 45 .

Qiu \& Bouché (1998) separated Ap. molleri, Ap. dubiosa and several other large-bodied greenish Franco-Iberian species into the newly erected Heraclescolex. If further molecular studies with more complete taxon sampling and wider gene selection prove their distinctness, the valid genus name would be Archeodrilus Szüts, 1913 with type species Criodrilus dubiosus Örley, 1881 by priority.

Acknowledgements - The study was supported by the Hungarian Scientific Research Fund (OTKA No. K100369).

\section{REFERENCES}

ChAng, C-H. \& JAMES, S. (2011): A critique of earthworm molecular phylogenetics. Pedobiologia, 54S: 3-9. doi: 10.1016/j.pedobi.2011.07.015

CsuZDI, Cs. \& POP, V. (2008): Taxonomic and biogeographic analysis of the Allolobophora sturanyi species group (Oligochaeta, Lumbricidae). Opuscula Zoologica, Budapest, 37: 23-28.

Dereeper, A., Guignon, V., Blanc, G., Audic, S., Buffet, S., CheVenet, F., Dufayard, J.F., GuinDON, S., LEFORT, V., LESCOT, M., ClAVERIE, J.M. \& GASCUEL, O. (2008): Phylogeny.fr: robust phylogenetic analysis for the nonspecialist. Nucleic Acids Research, 36: W465-W469. doi: 10.1093/nar/gkn180

DomíngueZ, J., AIRA, M., BREINHOlt, J.W., StOJANOVIĆ, M., JAMES, S.W. \& PÉREZ-LOSADA, M. (2015): Underground evolution: New roots for the old tree of lumbricid earthworms. Molecular Phylogenetics \& Evolution, 83: 7-19. doi: 10.1016/j.ympev.2014.10.024

Drummond, A.J., Suchard, M.A., XIE, D. \& RAMBAUT, A. (2012): Bayesian phylogenetics with BEAUti and the BEAST. Molecular Biology and Evolution, 29: 1969-1973. doi: $10.1093 / \mathrm{molbev} / \mathrm{mss} 075$

MRŠIĆ, N. (1991): Monograph on earthworms (Lumbricidae) of the Balkans I-II. Slovenska Akademija Znanosti in Umetnosti, Zazred za Naravoslovne Vede, Ljubjana, 757 pp.

RAMBAuT, A. (2014): FigTree v1.4: Tree Figure Drawing Tool. Available from: http://tree.bio.ed. ac.uk/software/figtree/. Accessed 2016 March 10.

SzEDERJESI, T. \& CSUZDI, Cs. (2015): A new earthworm species and new records from Albania with remarks on the molecular phylogenetic relationships of the Eisenia species of the Balkan Peninsula (Oligochaeta: Lumbricidae). North-Western Journal of Zoology, 11(1): 110-116.

TAmura, K., Stecher, G., Peterson, D., FiliPski, A., \& KUMAR, S. (2013): MEGA6: Molecular Evolutionary Genetics Analysis Version 6.0. Molecular Biology and Evolution, 30(12): 2725-2729. doi: $10.1093 / \mathrm{molbev} / \mathrm{mst} 197$ 